On the Shopfloor: exploring the

impact of teacher trade unions on

school-based industrial relations

Howard STEVENSON

School of Education, University of Leicester, 21 University Road, Leicester LE1 7RF,

UK

ABSTRACT Teachers are highly unionised workers and their trade unions exert an important influence on the shaping and implementation of educational policy. Despite this importance there is relatively little analysis of the impact of teacher trade unions in educational management literature. Very little empirical research has sought to establish the impact of teacher unions at school level. In an era of devolved management and quasi-markets this omission is significant. New personnel issues continue to emerge at school level and this may well generate increased trade union activity at the workplace. This article explores the extent to which devolved management is drawing school-based union representation into a more prominent role. It argues that whilst there can be significant differences between individual schools, increased school autonomy is raising the profile of trade union activity in the workplace, and this needs to be better reflected in educational management research.

Introduction

Teachers' tradition of collective organisation is as old as state education, and today teachers represent one of the most highly unionised sectors of any occupational grouping. Despite years of declining trade union membership across the economy, teacher unions have maintained, and recently increased, their membership (various sources, including Certification Officer and union records). Similarly, although general levels of industrial action are at historically low levels, in relative terms teachers appear more likely to engage in various forms of industrial action, up to and including strike action.

That teacher trade unions have been able to retain not only membership, but 
arguably influence, should be a matter of considerable interest. In recent years the education sector in general, and schools in particular, have experienced considerable restructuring. The shift to a more diverse and fragmented system, and the creation of quasi-markets, were introduced, at least in part, to undermine the influence of what were perceived as powerful producer interests. It can be argued that some policies, for example the abolition of teachers' negotiating rights, were deliberately ISSN 1363-2434 printed/ISSN 1364-2626 online/03/030341-16

DOI: $10.1080 / 1363243032000112829$

Downloaded by [University of Lincoln] at 04:21 10 April 2015

\section{$342 \mathrm{H}$. Stevenson}

introduced to weaken teachers' collective representation-their trade unions. Generally policies were predicated on a strongly held conviction within government circles that schools had fallen prey to 'producer capture' and that market forces were required to undermine the collective power of the providers (Omega Report 1984). Although in the face of these attacks teacher unions appear to have been resilient, the environment within which they function has clearly changed. Moreover, in the light of the current government's commitment to diversity and autonomy in the school sector (DfES 2001) it is likely to continue to change in ways that present the teacher unions with both challenges and opportunities.

Devolved management of schools has introduced new personnel issues into the workplace. Prior to 1988 the language of performance management, performancerelated pay and redundancy was largely unheard of in schools. Such issues now form part of the everyday vocabulary of school life. Increasingly key decisions affecting pay, conditions of service and teachers' general experience of work are taken at school level. These decisions will often reflect the specific market circumstances that are unique to each school.

In this environment, the traditional focus of trade union attention, national or 
LEA-level negotiating machinery, is often not appropriate-a school-based response is required. However, there is little empirical work that looks at the role of school-based union representatives. Industrial relations issues have tended to be neglected in educational management literature, whilst there is very little research which focuses on industrial relations at the level of the individual school. Research presented in this paper seeks to establish to what extent a more devolved and market-driven school system is generating a school-based system of industrial relations in which formal negotiating takes place between management and trade unions at the workplace. Are new personnel issues emerging at school level, and to what extent are these the subject of consultation and negotiation between managers and union representatives? Is it possible to identify specific factors which can explain varying levels of trade union activity between schools? This paper draws on recent research conducted in a large Midlands LEA to demonstrate the importance of recognising the trade union role in any analysis of school based issues of human resource management.

Background Early studies of school sector industrial relations focused strongly on the national structure and organisation of teacher unions (e.g. Tropp 1957; Coates 1972). This approach reflected the highly centralised nature of public sector industrial relations generally, and within the school sector in particular. Throughout the early part of the twentieth century the State had been keen to promote formalised and centralised bargaining structures for dealing with the pay and conditions of service of State employees. This system, known as Whitleyism, had its equivalence for school teachers in the form of the Burnham Committee which provided a national negotiating forum for dealing with pay (Busher \& Saran 1992).

Such a centralised and formalised structure within the public sector contrasted Downloaded by [University of Lincoln] at 04:21 10 April 2015 
The Impact of Teacher Trade Unions 343

sharply with industrial relations in the private, largely manufacturing, sector, where shopfloor bargaining, characterised by Flanders as 'largely informal, largely fragmented and largely autonomous' (1967: 552) was closer to the norm. As a consequence of this differing experience, studies of teacher trade unionism, such as those cited above, had little to say about the role of unions in the workplace. Their preoccupation was, understandably, with central and local government structures, reflecting Clegg's assertion that unions bargain at the level at which key decisions are made (Clegg 1979).

Although these analyses of teacher trade unionism were adequate for their time they became palpably inadequate as the highly centralised system to which they were integral began to fragment. Prior to the 1988 Education Reform Act, tensions within the system were becoming increasingly transparent, and the inability of the Burnham model to manage these tensions was equally clear. Burnham's death pangs are best illustrated by the protracted industrial dispute between 1984 and 1986 which must be seen as not simply a strike about pay, but as a watershed conflict over the management and control of teachers and teaching (Ball 1988). Although a 'national' strike, this conflict had considerable ramifications for industrial relations in individual schools, as local circumstances decisively shaped the experience of individual institutions. Following this dispute central government policy set about dismantling and undermining the traditional power bases of organised teachers, partly in the belief that an atomised system of self-managing schools would act as a restraint on militant trade unionism.

These reforms presaged the emergence of new personnel issues at a workplace level-a development well reflected in educational leadership and management literature which analyses the role of human resource management (HRM) in the post-1988 Act environment (see Riches \& Morgan 1989 and Bush \& Middlewood 
1997, for example). These texts provide detailed and well researched analyses of the development of HRM issues in the new self-managing schools, and draw important conclusions about good practice and implementation. However, a common feature of much of this work is that the impact and influence of teachers' collective representation on these key personnel issues is largely absent; an omission mirrored in the content of many postgraduate courses in educational management, and one that receives only modest attention in the government's training qualification for aspiring school leaders - the National Professional Qualification for Headteachers $(\mathrm{NPQH})$. Where attention is given to trade union involvement, this tends to focus on how unions at a national level seek to influence and shape government policythis is recognised for example by Saran (1992), and by Tomlinson (1992; 2000) in his analyses of performance-related pay and performance management. However, when scrutiny is focused on the implementation of performance management at school level the role of trade unions is absent (Reeves et al. 2002). Similarly, Dean's guide to implementing performance management (2002) makes reference to advice provided to members by national unions but offers no substantive guidance on working with unions at school level. Given the levels of trade union membership within the teaching profession, and therefore their likely impact on the application of these policies in the workplace, it is difficult to explain or justify this omission. Downloaded by [University of Lincoln] at 04:21 10 April 2015

\section{$344 \mathrm{H}$. Stevenson}

The most likely explanation can be traced to the emergence of school leadership and management literature from within mainstream theories of management and human resource management. Human resource management theorists have often had an uncomfortable relationship with trade unions, and therefore have had difficulty incorporating them into their analyses.

At the heart of the tension between HRM and trade unions is a difference in 
ideology and values. HRM approaches are firmly rooted in the unitarist management tradition which sees the interests of employer and employee as synonymous.

Any conflict in the relationship cannot be seen as either natural or inevitable, but rather must be considered as aberrant and irrational (Burchill 1992). Trade unions, acting as an alternative source of employee loyalty, are therefore perceived as divisive and disruptive. This antipathy towards trade union organisation is effectively summarised by Guest (1991), who argues that the 'values underpinning HRM leave little scope for collective arrangements and assumes no need for collective bargaining. HRM therefore poses a considerable challenge to traditional industrial relations and more particularly trade unionism' (Guest 1991: 43). In some cases such sentiments have received expression in an aggressive anti-unionism, reflecting the genesis of HRM from within non-union US businesses (Storey 1992). However, this is not inevitable and HRM in practice has often been utilised in parallel with collective bargaining structures. Indeed, Guest argues that where HRM is strategically introduced into organisations with a strong tradition of trade union organisation then a type of dualism tends to emerge in which HRM practices coexist with traditional collective bargaining arrangements (Guest 1991). This may well reflect the reality of experience in schools, although educational leadership and management literature tends to privilege one approach at the expense of the other in this dual system.

Whilst educational leadership and management literature has often underplayed the contribution of trade unions to shaping workplace HRM issues in schools, contributions from other sources have been more explicit in acknowledging their impact. For example, Wragg et al's study of the management of teacher competency asserts that 'Most teachers alleged to be incompetent turn to their union' (2000: 127) and this is reflected in a significant chapter devoted to the role of trade union officials in the management of capability procedures. Largely due to the focus on 
capability issues, Wragg et al's study drew on the experience of trade union officers external to the school (both lay officers and full-time officials). This reflects the serious implications arising from the use of capability procedures and therefore the need for experienced and skilled representation. This is an important area of study, but by definition it does not seek to analyse how trade unions shape more routine management issues in schools. Some more recent empirical studies of performance management and performance threshold implementation do appear to be addressing this issue (Haynes et al. 2002; Menter et al. 2002; Wragg et al. 2002). Arguably, the most comprehensive studies of school-based trade union activity are to be located within the field of mainstream management studies and industrial relations. Prior to the 1988 Act, Lyons, Stenning and McQueeney produced a report for the DES (1985) which provides an extensive summary of union involvement in Downloaded by [University of Lincoln] at 04:21 10 April 2015 The Impact of Teacher Trade Unions 345 school-based 'employment relations' (1985: 3) -the authors deliberately eschewed the term 'industrial relations' as inappropriate to the teaching profession. Following the 1988 Act, Ironside and Seifert's research (1995) specifically sought to assess the impact of devolved management on school-based employee relations. Ironside and Seifert argued that the creation of a quasi-market in school sector education, coupled with tight fiscal control by central government, was creating unavoidable tensions in the workplace:

This results in employers and managers behaving as if they were in the private sector and subject to the discipline of the market. The dominant slogan for managers in the private sector is 'more for less', that is productivity and/or efficiency gains at all costs. If this is the case, in crude terms, then an important issue for the management of recession in public services becomes the implementation of the necessary changes with the minimum 
of opposition. (Ironside \& Seifert 1995: 136)

Elsewhere Ironside, Seifert and Sinclair (1997) argue that employer pressures to increase productivity through labour intensification will inevitably meet resistance. Often this will be individualised (evidenced by increases in staff absenteeism, career changes and applications for early retirement), but often it will be collective. Indeed Ironside et al. argue that 'one of the central concerns of workplace trade unionism ...is to mobilise collective power to control management attempts to intensify exploitation' (Ironside et al. 1997: 123). This analysis treats conflict as inevitable, not aberrant.

Writing in the mid 1990s, Ironside et al.'s research provides a picture of school-based industrial relations in the years when LMS was becoming established. They argued that schools were beginning to establish formalised industrial relations along the lines that had previously existed at LEA level for dealing with procedural issues. However, formalised collective bargaining over substantive issues was not yet emerging. Rather Ironside et al. argued that whilst 'school teacher trade unions are deeply embedded in the workplaces' (1997: 131) their contribution remained largely informal-hence trade union involvement was still restricted to participating in consultative processes, rather than becoming engaged in more formal negotiating. Ironside et al. (1997) argued that continued dependence on informal approaches was the product of three factors. Firstly, they cite school size as an issue and suggest that the small size of many schools, primary schools in particular, militates against formal collective bargaining structures developing. Secondly, the existence of already established structures in schools such as staff meetings and consultation briefings tended to subsume new issues into old structures. Finally, Ironside et al. identified a reluctance on the part of both head teachers and school union representatives to become involved in more formalised negotiations over potentially conflictual issues. Instead the preference was to continue to rely extensively on 
support from LEA personnel officers and trade union officials.

In their study Ironside et al. questioned whether such continued informality was sustainable. Seifert suggested that increasing pressure on schools to improve performance, coupled with greater delegation of personnel issues to schools, would Downloaded by [University of Lincoln] at 04:21 10 April 2015

346 H. Stevenson

inevitably increase tensions (Seifert 1992). Furthermore, as tensions grew, the existing infrastructure of union lay officers and full-time officials would be unable to cope with the multiplication of bargaining units, a point acknowledged both within academic analysis (Barber 1992; Lawn \& Whitty 1992) and within teacher trade unionism (NUT 1992). In such circumstances the school union representative, willingly or unwillingly, might be expected to assume a more conspicuous role. Seifert therefore questioned the outcome of this emerging trend-would this 'presage the arrival of the school rep as workplace bargainer or remove the final vestiges of trade union influence from the schools?'(Seifert 1992: 11). Fieldwork conducted for this study seeks to provide a response to that question. Research Design

The study described in this article draws on research conducted in a large Midlands LEA, which during the course of the research was formed into three smaller LEAs following local government reorganisation. The size of the authority (426 schools) allowed for a range of schools to be covered with both urban and rural schools well represented. Schools involved in the research also represented the full range of school size with the number of teaching staff employed ranging from three to 100 ?] A range of research methods was used including three different questionnairescompleted by classroom teachers, head teachers and school union representatives. In order to ensure manageability a decision was taken to focus research on the 266 non-aided or controlled schools in the authority. The head teachers in all 
these schools received a questionnaire, and 174 replies were received (65\% response rate). NUT school representatives in these schools were also sent questionnaires, however, the sample was slightly smaller as it was known that in some schools there was no NUT membership, and hence no representative. The local union's mailing list was used to contact representatives, but it was clear that this was not totally reliable. It subsequently emerged that questionnaires had still been sent to schools where there was no representative, suggesting that the actual response rate was higher than the official figure of $35 \%$. Two hundred and fifty two questionnaires were distributed to union representatives and 89 replies were received. The selection of schools for the classroom teacher questionnaire was based on a stratified random sample, designed to ensure an appropriate balance between primary and secondary phases. After access had been granted 1321 questionnaires were distributed to classroom teachers, and 403 (31\%) were returned. Distribution to teachers was coordinated by the head teacher in each school; however, there was evidence that in some cases questionnaires were received at the school, but not passed on to staff. It was not possible to quantify the scale of this problem, although it was unlikely to be significant. However, it does have a bearing on the response rate, which in reality is higher than the figure indicated above.

Questionnaire data was supplemented by semi-structured interviews that were conducted with head teachers (13 interviews), school union representatives (10) and local union lay officers (5). Schools were randomly chosen from within the sample Downloaded by [University of Lincoln] at 04:21 10 April 2015 The Impact of Teacher Trade Unions 347 of schools completing the questionnaires. Where possible, efforts were made to interview both head teacher and union representative in the same school. Finally, a wide range of meetings was observed (primarily local union branch meetings and LEA-level negotiating/consultative committees) and documentation 
was gathered from local union branches, LEA committees and schools involved in the fieldwork.

At an early stage it was decided to focus the research on the activities of the National Union of Teachers (NUT). The NUT was, and still is, the largest teachers' union (although it is not as pre-eminent in membership terms as it once was). Within the case study LEA the NUT was the pre-eminent teachers' union, having the largest membership and occupying a majority of the positions on all local negotiating bodies. Within this research much of the data is not specific to a particular union, but it is important to be aware that questionnaire data referring to union representatives is based on information provided by NUT members.

Research Findings

The Trade Union Profile in Schools

Measuring union density can pose many difficulties (Bain \& Price 1983), however, within the teaching profession the task is perhaps more straightforward-the potential membership is relatively homogenous (although with the emergence of so-called 'para-professionals' even this may be changing) and the definition of a trade union in this sector is largely unproblematic. By almost any criteria the extent to which members of the teaching profession are members of a trade union is a striking feature. Although there may have been shifts between unions in recent years it is still the case that very many teachers continue to belong to an organisation that calls itself a trade union. As part of this research the questionnaire to classroom teachers indicated that $93 \%$ of respondents were trade union members. Such a figure places teachers well above the national average for trade union membership; for example, current union density levels across the private sector are 19\% (The Guardian, 5 September 2002).

This high level of union membership is further reflected in the presence of a significant number of school representatives - those individuals who act as a contact 
point for members of their union and who may take on the role of representing union members' individual and collective interests to the management of the school. Questionnaire evidence from head teachers indicated a high proportion of schools having some trade union representation within the school, although the fieldwork highlighted some significant differences between phases and between unions. It is clear from these results that there is a significant difference between the primary and secondary school sectors with appreciably higher levels of representation in the secondary sector experienced by all unions except the Professional Association of Teachers (PAT). This picture of higher levels of union organisation and activism within the secondary sector is a theme that is reflected throughout this research. It points to the significant cultural differences that tend to exist within Downloaded by [University of Lincoln] at 04:21 10 April 2015

$348 \mathrm{H}$. Stevenson

TABLE I. Active workplace representation in schools by trade union-as reported by head teachers Which of the following unions have active workplace representation at your school? Primary (\%) Secondary (\%)

ATL 6491

NASUWT 4589

NUT 8898

PAT 4547

Other 616

n国126 n回47

smaller organisations. In this sense these findings are entirely consistent with research elsewhere (Millward et al. 1992) which points to a strong correlation 
between workplace size and trade union organisation.

Differences between unions, and particularly the pre-eminence of the NUT in both sectors, is in part explained by geographical factors-the case study LEA was dominated by the NUT and this situation will not be replicated across all LEAs. However, the results do point to the NUT's traditional strength across both sectors, in contrast for example to the National Association of Schoolmasters Union of Women Teachers (NASUWT) which has tended to be stronger in the secondary sector. High figures for the NUT also reflect its historical commitment to a type of industrial unionism which has always placed a premium on workplace organisation (Carlson 1987). This contrasts with the differing historical traditions of a union such as the Association of Teachers and Lecturers (ATL), based more closely on a model of 'professional unionism' (Heery \& Kelly 1994).

Notions of 'active workplace representation' however require further clarification, recognising that it is perfectly possible for a school representative to play an active role in promoting the union to its members, but may take no part in representing their individual and collective interests to management. Head teachers were invited through interviews to describe the decision-making structures and processes that existed within their schools. The aim was to establish to what extent trade union representation featured in these processes. A strong theme that emerged from their responses was an accent on 'collegiality' -an emphasis on collaborative working and teamwork, suffused with a language of 'professionalism' in which craft skills and expertise are acknowledged and recognised. Head teachers generally presented themselves as 'democratic' leaders-developing and coordinating the staff team around shared objectives. This was articulated by one head teacher in the following terms:

The key to this is that we are a professional organisation. The people here are more able to do some jobs than the Principal can possibly be. Management 
has to be based on consultation and the regular exchange of advice.

Downloaded by [University of Lincoln] at 04:21 10 April 2015

The Impact of Teacher Trade Unions 349

My function is to try to hold the staff together as a whole, and also the governing body as a whole, and to get them to relate together. (Head teacher, secondary school)

This emphasis on developing the staff team was reflected in the high priority given to the whole staff meeting as a means of both communication and consultation. Responses to the head teacher questionnaire indicated that every head teacher held whole staff meetings at least termly. However, the questionnaire results revealed significant differences between the primary and secondary phases. Primary schools were far more likely to meet as a whole staff on a weekly basis ( $91 \%$ of primary head teachers indicated that this was the case), whereas in the secondary sector whole staff meetings were most likely to take place monthly ( $46 \%$ of respondents) with a significant proportion (28\%) indicating they met as a whole staff termly. These differences between the primary and secondary phases were reflected in the differential use of other means of communication, such as team leader meetings and meetings with school union representatives. Seven per cent of head teachers indicated in the questionnaire that they held regular, scheduled meetings with union representatives, whereas $73 \%$ of head teachers met with their union representatives on an ad hoc, 'when necessary' basis. Twenty per cent of head teachers never met with their union representatives. However, within the primary sector only $1 \%$ of head teachers indicated that they held regular scheduled meetings, whilst the figure for not meeting at all was $25 \%$. In the secondary sector these figures are virtually reversed $-23 \%$ had regular scheduled meetings with union representatives (usually monthly) whilst only $4 \%$ claimed not to meet with union representatives at all. These figures reinforce the view that in the secondary sector especially, union 
representatives are an established part of the employee relations machinery. It is also important at this stage to unpick in a little more detail the significance of the primary/secondary divide. For example, whilst $23 \%$ of secondary head teachers having scheduled meetings with union representatives will probably cover a similar proportion of secondary teachers in the LEA, because of wider variations in school size this may not be the case in the primary sector. If within the $25 \%$ of primary schools indicating there is no contact with union representatives there is a high proportion of small rural primary schools, then the proportion of teachers without this sort of union representation will be very much smaller.

In addition to school-based representation the questionnaire evidence indicated a significant amount of contact between head teachers and either local union lay officers or full-time officials. Interviews with head teachers, union officers and school union representatives indicated that this type of intervention was most commonly in response to casework demands on behalf of individual members. Situations involving the use of formal capability, disciplinary or grievance procedures, for example, almost always involved outside union intervention-a finding which reflects Wragg et al.'s study (2000). These types of issues are highly complex, very time-consuming, and there is much at stake in terms of individuals' livelihoods. School union representatives who were interviewed showed no enthusiasm for getting involved in this type of representation. As a consequence, head teachers Downloaded by [University of Lincoln] at 04:21 10 April 2015

$350 \mathrm{H}$. Stevenson indicated that in $6 \%$ of cases they had had 'frequent' contact with local lay officers in the previous 12 months, whilst a further $31 \%$ reported some contact. Whilst not as high, the figures for full-time union officials were still high in relative terms $-22 \%$ of head teachers reported 'some' or 'frequent' contact with this type of union representative. 
It is significant that secondary schools experienced considerably more involvement from both local lay officers, and full-time officials. This suggests that external union involvement was not in lieu of school-based representation, but in addition to it. The more effectively organised the school-based representation was, the more likely it would be that additional support would be brought in from outside. Headteacher-Trade Union Relations: identifying the issues Having established that there is significant contact between head teachers and trade union representatives, it is important to establish precisely what issues are the subject of this interaction. Through the use of the questionnaire head teachers were asked to identify what issues were raised with them by union representatives and the frequency with which these issues were raised.

The wide range of issues over which there is contact between head teachers and school union representatives tells us much about the involvement of school union representatives in the day-to-day management of schools. Across the diverse range of issues listed, the survey indicated that at least some head teachers had some contact with representatives on every one of the items identified-given that the list ranged from staple conditions of service issues, through professional issues relating to curriculum and assessment to wider issues of training and professional development, then this is significant. However, it should be noted that on very many of the issues identified contact is clearly limited to relatively few instances. Those issues most frequently identified by head teachers reveal much about the pressure points in schools, some of which are relatively new features of school-based employee relations. The area over which there appears to be most frequent contact is health and safety issues with $55 \%$ of respondents indicating contact on this issue. Such a result should not be surprising given the centrality of health and safety as an area of traditional trade union bargaining. However this relatively high figure might be explained further by both the broad range of issues covered by the umbrella title 
'health and safety', and also the presence in many schools of separate trade union health and safety representatives (cited in only $11 \%$ of primary schools, but $50 \%$ of secondary schools).

Just below health and safety, head teachers cite workload (51\%) as the issue over which they have the most frequent contact. Again, the result suggests that 'bread and butter' trade union issues continue to be the staple of discussions between union representatives and their head teachers in schools. This result also anticipates the emergence of this issue as one which has now assumed national significance in discussions between the Government, teacher unions, local authority employers and the School Teachers' Review Body. The questionnaire helps shed some light on what particular workload issues present as problems, and the perDownloaded by [University of Lincoln] at 04:21 10 April 2015

The Impact of Teacher Trade Unions 351

TABLE II. Teacher union representative contact with head teacher-by issues, and as reported by head teachers

How often do teacher union representatives based in your school contact you about the following issues? ( $\mathrm{n}$ [174 for all responses)

Often (\%) Sometimes (\%) Never (\%)

Salaries 14158

Premature retirement 22870

Redundancy 22672

Redeployment 12178

Health \& Safety 124345

Sex discrimination 01090

Race discrimination 1891

Disciplinary 11782

Workload 74449 
Pensions 02080

Holidays 01882

Sickness absence 11782

Leave of absence 12475

Appraisal 33760

Staffing levels 53065

Curriculum \& Assessment 73855

Temp contracts 32374

Part-time contracts 11881

Maternity leave 11584

Travel Allowances 01189

Working hours 23266

Job descriptions 53461

Promotion 11881

Cover 52174

Training 22375

Professional Competence 11287

ceived causes of increases in workload. Some clues to these questions are presented by responses elsewhere in the table-the next most frequently raised issues are curriculum and assessment (45\%), appraisal (40\%), salaries (40\%), job descriptions (39\%), staffing levels (35\%), early retirement (30\%) and redundancy (28\%). Inevitably the types of issues raised by union representatives will ebb and flow over time, reflecting a range of prevailing circumstances. For example, at the time the questionnaire was carried out, 'staffing levels' largely reflected concerns about class size. More recently, the same issue has assumed importance because of problems arising from staff shortages and teacher vacancies. This shift was reflected in interview evidence with trade union officers, who also cited pupil behaviour/management 
and supporting members in schools in serious weaknesses/special measures as a major source of both individual and collective casework. These issues had not been included in the original questionnaire.

Downloaded by [University of Lincoln] at 04:21 10 April 2015

\section{$352 \mathrm{H}$. Stevenson}

What is significant, however, is that many of the issues that scored highly in the questionnaire are relatively 'new' issues as the subject of school-level discussion. As such, they reflect a changing environment in which increased school autonomy appears to be generating new issues for school-based bargaining. Appraisal, and more recently performance management, have now become an established feature of working life in schools. It should not come as a surprise if employees seek collective representation over the implementation of an issue that impacts on their workload, their job control and their pay. Indeed pay, and more specifically the emergence of performance pay, regional pay and the use of flexibilities to reward working nonstandard hours, may yet prove to be the issue that ignites workplace trade unionism in some schools. Indeed the first signs of regional and even school-based industrial action over pay are already emerging. Evidence from this research suggests that as pay variations by workplace increase, so too will the activity of trade union representatives. Such a development may presage a transition from informal consultation with trade unions to a more traditional style of collective bargaining and formal negotiation.

Interview evidence indicated that in many cases head teachers will seek solutions to managing change which make no use of teachers' collective organisation. The mainstream HRM response of clear communication, effective teamwork and individual contact will form the basis of the favoured approach. This position, which consummately reflects the unitarist approach, was summarised as follows: We've got members of all unions here, but we do not meet as union 
representatives. If there was a conflict [referring to national action] I would support it. I would not undermine it. But staff never bring me those sorts of problems. Members are instrumental here-we prefer a team approach. (Head teacher, primary school) Trade unions are often perceived as useful for making policy representations to government and for providing legal and insurance service to members but it is not envisaged that they have any workplace role. It is important to recognise that this approach was found almost exclusively in the primary sector, and most often in the case of small primary schools. As school size developed, the relationship became more complicated and complex.

In several interviews head teachers described how they actively and positively engaged with their trade union representatives. Such processes were seen as helpful in improving communication and decision making whilst often avoiding the development of unnecessary problems and conflicts. Trade unions in this sense were used as 'sounding boards' to assist decision making. One head teacher described his relation with teacher union representatives in the following terms: We have regular monthly meetings, during lesson time. They're not minuted-we try to keep them informal. The meetings are a vital barometer of what staff are thinking. A number of issues have come up which we have tested out on the unions. They've either supported them or not supported them. Generally it has been very wise advice. It has certainly Downloaded by [University of Lincoln] at 04:21 10 April 2015 The Impact of Teacher Trade Unions 353 prevented major conflicts with staff. It has prevented going down a route that might subsequently be damaging or require a u-turn. I use them and rely on them. (Headteacher, secondary school) A feature of this type of approach was an understanding of, and respect for, the 
representative role of the trade union. Unions could be helpful in providing solutions to problems and for offering observations on strategic policy options. However, this could not always eliminate conflict and in such situations trade unions offered a way of dealing with conflict in a less personal and more detached way. The same head teacher made the point thus:

We've always had good relationships. They certainly haven't deteriorated. During the redundancy process they've been very supportive, and we've worked together. However, we will reach the point soon, within days, when they will of necessity adopt a non-cooperation line because obviously they cannot support the sacking of their own members. I expect that and respect their view.

This approach of working with trade unions, whilst recognising the legitimacy of potential, and indeed at times inevitable, conflict was not echoed by all head teachers. Interview evidence demonstrated much more reluctant attitudes towards engaging with trade unions, and in these cases there was a clear view that the trade union role should only-could only-be consultative. The following comments refer to the formulation of a school pay policy.

I think that it is appropriate, but I don't think it is essential that unions are involved because of the way it is structured [the consultation] with people having the chance to give their views. They [the unions] are entitled to comment... but I don't see that it is an endorsement that everyone should look for. It is about people working with people. (Head teacher, primary school) In this case the head teacher explicitly rejects the notion of the need to achieve a collective agreement of the type that is a feature of bona fide negotiation. Instead, the role of trade unions is restricted to a consultative one in which views may be expressed, but not necessarily acted upon. This rather reluctant attitude is expressed 
more cynically by another head teacher.

There are regular meetings [with union representatives]. I have to keep them sweet. I'm afraid there's a rather nasty tradition here. If there's an issue they call a union meeting straight away, rather than coming to me and saying there is a concern about whatever. They like to be consulted. I obviously have the power of veto. (Head teacher, secondary school) Conclusion

The research confirms that schoolteachers remain a highly unionised profession, despite long-term trends of declining union membership across the economy and the Downloaded by [University of Lincoln] at 04:21 10 April 2015

\section{H. Stevenson}

introduction of specific policies designed to weaken teacher union influence. However, it is clear that the terrain on which industrial relations is now played out has altered significantly from the days of the Burnham Committee and powerful LEAs. The post-1988 Education Reform Act agenda, introduced by the Conservatives and pursued energetically by New Labour, has fundamentally altered the space in which teachers' collective interests are expressed. The creation of autonomous schools, competing for resources, and against each other, has not only introduced new issues into school management, but importantly, has also introduced new pressures. The drive to improve performance, whilst containing costs, presents management with the classic business challenge - to decrease unit labour costs by driving up productivity and restraining pay.

The drive for improved performance, and the introduction of new control mechanisms to both motivate and measure labour productivity, will often be contested by teachers. In some cases contestation will mean seeking to mediate the nature of reform, in other cases contestation will mean resistance. Strategies of mediation and resistance will be many and varied, sometimes active, sometimes 
passive; sometimes individual, sometimes collective. Whatever the response, it is important to recognise that trade unions play an important role in articulating teachers' response to reform and restructuring, and that ignoring the contribution of teacher trade unions to shaping educational change represents a significant omission.

The research in this paper identified substantial variation in the level of workplace trade union activity between schools and it is clear that a significant factor in explaining this variation is school size. Trade union organisation is less common in smaller workplaces and schools are no exception to this rule. However the relationship is not always simple and straightforward, with other factors also shaping the issue. The attitude of head teachers is clearly important in shaping the extent to which trade unions are able to influence key decision-making processes in schools. Many head teachers in the research had frequent contact with their trade union representatives and valued the benefits of this contact. In other cases head teachers engaged in contact with union representatives reluctantly, and in these cases head teachers were keen to make clear that the contact was purely consultative. It is my contention that this latter position will become increasingly unsustainable as the current reform agenda continues apace. The growth of new issues as the subject of workplace bargaining is already transforming school-based industrial relations and the emergence of the key issue, pay, may well prove to be decisive. It is likely therefore, that willingly or not, head teachers will increasingly find themselves dealing with union representatives, in a manner which may go beyond mere consultation, and increasingly take on the characteristics of bona fide negotiation. However, trade unions, in their turn, may view this prospect with concern. Whilst research pointed to new issues driving a new school-based unionism, it was far from clear that representatives at the workplace were willing or able to take on these heightened responsibilities. At very least the teacher unions will have to 
consider how they most effectively support their school-based representatives, addressing their needs for information and training. At a wider level, teacher unions

Downloaded by [University of Lincoln] at 04:21 10 April 2015

The Impact of Teacher Trade Unions 355

will have to consider how best they deploy their full-time officials and lay officers to cover the emergence of plant-bargaining across the country's schools. Arguably it is this latter issue, more than any other, that genuinely opens up the prospects of merger between some or all of the major teacher unions.

Acknowledgements

I am grateful to Mark Brundrett for his comments on an early draft of this article, and for the comments of the two anonymous referees.

REFERENCES

Bain GS \& Price R (1983) Union Growth: dimensions, determinants and destiny in Bain GS (Ed.) Industrial Relations in Britain, Oxford: Blackwell.

Ball SJ (1988) Staff relations during the teachers' industrial action: context, conflict and proletarianisation, British Journal of Sociology of Education, 9(3), 289-306.

Barber M (1992) Education and The Teacher Unions, London, Cassell.

Burchill F (1992) Labour Relations, London: Macmillan.

Bush A \& Middlewood D (eds) (1997) Managing People in Education, London: Sage.

Busher H \& Saran R (1992) Teachers' Conditions of Employment: a study in the politics of school management, London: Kogan Page.

Carlson D (1987) Teachers as political actors: from reproductive theory to the crisis of schooling, Harvard Educational Review, 57(3), 283-307.

Clegg H (1979) The Changing System of Industrial Relations in Great Britain, Oxford: Basil Blackwell.

Coates R (1972) Teachers' Unions and Interest Group Politics: a study in the behaviour of organised teachers in England and Wales, Cambridge: Cambridge University Press. 
Dean J (2002) Implementing Performance Management: a handbook for schools, London: Routledge-

Falmer.

DfES (2001) Schools Achieving Success, London: The Stationery Office.

Flanders A (1967) Collective bargaining: prescription for change in Flanders A Management and Unions: the theory and reform of industrial relations, London: Faber.

Guest DE (1991) Human resource management: its implications for industrial relations and trade unions in Storey J (ed.) New Perspectives on Human Resource Management, London: Routledge.

Haynes GS, Chamberlain RP, Wragg EC \& Wragg CM (2002) Being managed: Performance Management from the teachers' point of view, paper presented at BERA Annual Conference, Exeter, 13 September.

Heery E \& Kelly J (1994) Professional, participative and managerial unionism: an interpretation of change in trade unions, in Work, Employment and Society, 8(1), 1-22.

Ironside M \& Seifert R (1995) Industrial Relations in Schools, London: Routledge. Ironside M, Seifert R \& Sinclair J (1997) Teacher union responses to education reforms: job regulation and the enforced growth of informality, Industrial Relations Journal, 28(2), 120135.

Lawn M \& Whitty G (1992) The re-formation of teacher unionism, Education Review, 6(1), 4-12.

Lyons G, Stenning R \& McQueeney J (1985) Employment Relations in Maintained Secondary Schools, Bristol: National Development Centre for School Management Training. NUT (1992) The Next Five Years: implications for the union-consultation paper, NUT internal paper.

Menter I, Mahony P \& Hextall I (2002) 'Getting through', 'getting on' or 'getting out'? The impact Downloaded by [University of Lincoln] at 04:21 10 April 2015

356 H. Stevenson

of Performance Threshold Assessment on schools in England, paper presented at BERA Annual 
Conference, Exeter, 13 September.

Millward N, Stevens M, Smart D \& Hawes W (1992) Workplace Industrial Relations in

Transition: the ED/ESRC/PSI/ACAS surveys, Aldershot: Dartmouth.

Omega Report (1984) London: Adam Smith Institute.

Reeves J, Forde C, O'Brien J, Smith P \& Tomlinson H (eds) (2002) Performance Management

in Education: improving practice, London: Sage.

Riches C \& Morgan C (eds) (1989) Human Resource Management in Education, Milton Keynes:

Open University Press.

Saran R (1992) The history of teachers' pay negotiations in Tomlinson H (ed.) Performance-

Related Pay in Education, London: Routledge.

Seifert R (1992) Changing role of the school rep, Managing Schools Today, 1(6), 8-13.

Storey J (1992) Developments in the Management of Human Resources, Oxford: Basil Blackwell.

The Guardian (2002) Monks warns Blair over 'bottling out', 5 September.

Tomlinson H (1992) Performance-related pay in the 1980s: the changing climate in Tomlinson

H. (ed.) Performance-Related Pay in Education, London: Routledge.

Tomlinson H (2000) Proposals for performance related pay for teachers in English schools, School Leadership and Management, 20(3), 281-298.

Tropp A (1957) The School Teachers, London: Heinemann.

Wragg EC, Haynes GS, Wragg CM, Chamberlain RP (2000) Failing Teachers? London:

Routledge.

Wragg EC, Wragg CM, Haynes GS \& Chamberlain RP (2002) The experience and reactions

of two groups of teachers who did not cross the pay threshold, paper presented at BERA Annual Conference, Exeter, 13 September.

Notes on Author

Howard Stevenson is a lecturer in the Centre for Educational Leadership and Management at the University of Leicester, where he teaches on the Master's and Doctoral programmes. In addition to school sector industrial relations he has current research interests in the links between 
education policy, school leadership and social inclusion.

E-mail: hps2@leicester.ac.uk 